\title{
The Impact of Availability of Practical Guidance on School Management on Managerial Capabilities of Kindergarten School Principals in Medan City
}

\author{
Aman Simaremare $^{1 *}$, Nasriah ${ }^{2}$, Dorlince Simatupang ${ }^{3}$, Elya Siska Anggraini ${ }^{4}$ \\ ${ }^{1-4)}$ Lecturer of Early Childhood Education Program at State University of Medan \\ *tuansimare@unimed.ac.id
}

\begin{abstract}
This study aims to describe the impact of the availability of practical school management guidelines on the managerial ability of Kindergarten principals in Medan City. This type of research is a descriptive study. The target population of this study is the whole Principal of Kindergarten in Medan with a sample unit of 20 principals taken randomly. Data collection techniques were carried out using questionnaires and documentation, then the data were analyzed descriptively in the form of percentage analysis. The results showed that principals' managerial ability before the school management practical guidance was available tended to be in the category of very less $25 \%$, the category was less than 18.75 , and the category was quite $25 \%$, while the good category was only $31.25 \%$. After the existence of a practical guide to school management, school managerial ability tends to increase in the good category of $56.25 \%$, the enough category is $12.5 \%$, while the less category is $6,25 \%$ and the category is very less $25 \%$. The conclusion of the study shows that there is a positive impact of the availability of practical guidelines for school management on the managerial ability of the Kindergarten principals in Medan.
\end{abstract}

Keywords: practical guide, school management, managerial ability, principal

\section{Introduction}

Kindergarten School (KS) is a formal path education unit held before the level of basic education which focuses on laying the foundation towards physical growth and development (fine and gross motor coordination), intelligence (thinking power, creativity, emotional intelligence, spiritual intelligence), socio-emotional (attitude and behavior as well as religion), language and communication, in accordance with the uniqueness and developmental stages that are passed by early childhood [1].

The nursery school is led by a school principal who is responsible for the sustainability of the school. The management and organization of kindergartens must be carried out in accordance with PAUD national standards in order to realize quality PAUD [2]. Kindergarten in Medan can be said to be growing rapidly. According to an online SIAP database, there are 732 kindergartens and the like there are 732 schools consisting of 730 private kindergartens and 2 public kindergartens Pembina. However, from the initial search results that most of the kindergarten schools in Medan, the management and implementation did not meet the prescribed PAUD standards.

Quality kindergarten is the hope of all elements of society and government. Quality schools cannot be realized by an instant process but through a relatively long process whose control is carried out by qualified human resources especially principals in addition to the 
involvement of teachers and other education personnel. This means that the back and forth of a school is in the hands of the principal as a manager (manager). In line with this statement Deming an American who is one of the company's consultants in Japan stated that the problem lies in essence the concept of management, especially the failure of senior managers in the planning process $[3,4]$. Further said to improve quality in an organization, managers must concentrate on mistakes or failures of past management to be used as a basis for planning in the future and to predict problems that will occur. This Deming Statement confirms that the manager's role is very strategic in controlling the quality of an organization. In school perspective, it means that the principal as an education manager in a school plays a strategic role in controlling school quality.

The problem of the quality of education is inseparable from the problems of education management. Sagala [3] states that education management problems consist of macro education problems and micro education problems. The problem of school quality is a microeducational problem related to management quality. Schools as an organization engaged in education services, must be managed properly by an education manager in this case the principal. Principals must be able to think reflectively on failures or mistakes. Therefore, a professional headmaster must have personal competence, managerial competence, entrepreneurial competence, supervisory competence, and social competence in accordance with the demands in Permendiknas No. 13 /2007 concerning Standards for School / Madrasah Principals.

The quality conditions of TK schools in Medan have not been satisfactory in accordance with the expectations and standards of PAUD. The results of the interim analysis showed that principals in kindergartens of more or less $85 \%$ could not be categorized as professional principals because in general kindergarten principals did not yet have a principal certificate as a demand from regulation Permendiknas No. 13/2007. Even there are still kindergarten principals who do not have educational qualifications in accordance with the demands of the Teacher and Lecturer Law of 2005, as a result the quality of management carried out by principals is less satisfactory. Therefore the principal's role as a school manager is expected to try to develop the school towards the quality expected by all parties to educational services. The principal must work harder to think and act to develop a quality school that can be realized through a strategic management action.

One of the competencies that must be possessed by professional school principals in order to plan kindergarten programs towards good quality is managerial ability. Managerial ability is the ability of the principal in carrying out management functions in managing the school both human resources and other resources such as the ability to manage, coordinate and move school personnel towards achieving the goals set by the school organization.

The failure of a school manager to produce quality schools can occur because of several things, including the principal not understanding the expected performance of his position as a leader of the working group, lacking understanding of the managerial role that he bears, does not have the managerial skills needed to produce targeted managerial performance, or weak in terms of motivating or moving the people they lead.

In connection with the description of the above problems it is necessary to make an effort to help the kindergarten principal in improving his managerial skills through the development of a practical management guide that can be used as a principal for the school in carrying out his duties and functions as a school manager. This research will try to answer the research problem, what and how can the availability of practical management guidelines improve the managerial ability of principals in the management of kindergartens in Medan. 


\section{Managerial Ability}

Management is a simultaneous and systematic effort to achieve common goals. All kinds of human activities in daily life are related to management. According to Terry [5] that management is the power that governs a business, and is responsible for the success or failure of its business. Management deals with the organization of an organization's activities from planning to achieving the desired results using other people.

Kartono [6] reviewed the notion of management as controlling a business, which is the process of delegating / controlling authority to several responsible persons with leadership tasks and the process of mobilizing and guiding control of all human resources and material resources in the activities of achieving organizational goals. Furthermore Hersey and Blanchard (1982) define management as a process of working together through people or groups to achieve organizational goals.

Observing the above understanding it can be stated that management is related to human activities to utilize all available resources in an organization both human resources and material resources effectively and efficiently for the achievement of organizational goals. In school management school perspective means the activities carried out by the school principal to utilize all available resources in the school both human resources (school personnel) and school material resources effectively and efficiently in order to achieve the goals of the school institution.

The activity of a manager in managing an organization shows a series of process activities that take place systematically with the main goal leading to the achievement of organizational goals. According to Terry [5] the management process can be seen from the application of management functions which include four activities namely: planning, organizing, actuating, and controlling (POAC). Then according to Stoner [7] the management process consists of: planning, organizing, leading, and controlling (POLC). The management process that is not much different from the previous opinion consists of planning, organizing, directing, and controlling abbreviated as PODC $[8,9]$. Another slightly different perpendicular was stated by Kartono [6] that the manager's function includes planning, organizing, leadership, and evaluating abbreviated as POLE.

Although the management process put forward by experts shows that there are differences in the terms used but when examined from the explanations contained in the different terms, there will be found similarities in activities, such as the actuating, leading and directing functions, then controlling with evaluating. This means that the term is conceptually sufficiently problematic but does not need to be questioned in its application. According to Drucker [10] the success of a manager can be measured by two concepts, namely efficiency (efficiency) and effectiveness (effectivity). An efficient manager is a manager who achieves maximum results, while an effective manager is a manager who is able to choose the right job to do.

Management skills that need to be mastered by a manager in order to realize the achievement of organizational goals effectively and efficiently there are three fields namely technical skills, human skills, and conceptual skills $[11,12]$. Technical skills are the expertise of managers using the knowledge, methods, procedures, techniques and reason needed to carry out a particular task for which they are responsible. This ability is generally obtained through experience, education, and training. Human skills are the ability of managers to work well with others individually or in groups. Managers know how to communicate, motivate, lead, and generate enthusiasm and trust. Conceptual skills are the ability of managers to think and conceptualize abstract and complex situations. Managers are able to see a particular organization as a whole, understand the links between various types of organizational 
conditions that occur within an organization and can utilize them in making appropriate decisions when facing a problem in the organization.

When noted, the ability or expertise that must be possessed by a manager, then in the perspective of schooling the principal must have the ability or management expertise such as conceptual expertise, technical expertise, expertise in human relations, communication skills, effectiveness skills, and interpersonal skills so that the organization schools can run effectively as managers of quality learning. The expertise intended to be mastered by the principal is regulated in regulations made by the government through Permendiknas No. 13 of 2007.

This Regulation of the Ministry of Education regulates the special requirements to be the Head of Kindergarten / Raudhatul Athfal (TK / RA) namely: 1) having the status of a TK / RA teacher, 2) having an educator certificate as a TK / RA teacher, and 3) having a TK / RA head certificate RA issued by an institution established by the government. Besides that, it is also regulated the competencies that must be possessed by a TK / RA head in carrying out his duties, one of which is managerial competence.

Danim and Khairil [13] suggested that the abilities that principals must have as managers in order to carry out their roles and functions in school management in line are: 1) able to implement appropriate strategies to empower school personnel in accordance with their potential, providing opportunities for personnel schools to improve their profession, and encourage the involvement of all school personnel in various activities that support school programs, 2) able to optimize and access school resources to realize their vision, mission, and achieve their goals, be able to formulate programs, organize and empower personnel, and utilize resources superior school power, and 3) able to delegate tasks, allocate work, set quality standards, monitor results, control costs, and others.

The effectiveness of the principals 'managerial tasks implementation is inseparable from the managerial ability of the principals' abilities. This can be seen from the results of previous studies, including: 1) there is a positive and significant effect on managerial ability on school effectiveness with a correlation coefficient of 0.474 [14]. 2) madrasa head managerial ability contributes significantly to madrasa quality and is in the strong category, teacher teaching performance contributes significantly to madrasa quality and is in a strong enough category, and together madrasa head managerial ability and teacher teaching performance contribute significantly on the quality of madrasas and are in the strong category [15]. 3) there is an effect of the principal's managerial ability on teacher performance by $59 \%$ [16], and 4) the managerial ability of the principal and work motivation influences the performance of SLB teachers in Subang by $54.5 \%$ [17].

\section{Practical Guidelines for School Management}

Management practical guidelines are manuals published with practical forms and content presentation techniques that mainly contain various kinds of information about school management.

The contents of this practical management guide consist of: the nature of education management, school planning and development, school change leadership, school culture and climate, school curriculum management, management of educators and education staff, management of school relations with the community, management of school facilities and infrastructure, management of participants students, school financial management, school administration and special service management, management information systems and school communication technology management, and monitoring and evaluation of school activities.

The principal as a school manager performs his role and function to empower teachers and education personnel in various activities that support school programs. The principal must 
optimize and access school resources other than humans to realize the school's vision, mission and goals.

In connection with the duties and roles of school principals in realizing schools towards better quality, they need to be assisted to improve their abilities, expertise or managerial skills both technical skills, human management skills, and conceptual skills through the development of practical management guidelines that can be guided and studied self-taught a school principal. Thus it is assumed that the availability of practical management handbooks can improve the management capabilities of school principals in the framework of managing and administering schools towards better quality.

\section{Research Method}

This study uses research and development methods (research and development) developed by Borg \& Gali [18] to produce products in the form of practical management manuals and test the effectiveness of these products on improving the principal's managerial ability. This research was conducted at the Kindergarten Principal in Medan City. The research data was obtained using a questionnaire, interview and documentation analysis, and then the data were analyzed descriptively in the form of percentage analysis.

\section{Results and Discussion}

This section presents research data to describe the managerial implementation of school principals and the impact of practical school management guidelines on the managerial implementation of kindergarten principals in Medan. Research data can be seen in Table 1.

Tabel 1. Description of the Principal's Managerial Task Implementation Before and After the Availability of Practical Guidelines for School Management

\begin{tabular}{|c|c|c|c|c|c|}
\hline \multirow{3}{*}{ No } & \multirow{3}{*}{ Managerial Task Implementation } & \multicolumn{4}{|c|}{ Implementation } \\
\hline & & \multicolumn{2}{|c|}{ Before } & \multicolumn{2}{|r|}{ after } \\
\hline & & $\%$ & Information & $\%$ & Information \\
\hline 1 & $\begin{array}{l}\text { Develop school plans for various levels of } \\
\text { planning }\end{array}$ & 5 & $\mathrm{C}$ & 5 & B \\
\hline 2 & Developing schools according to needs & 5 & B & 5 & B \\
\hline 3 & $\begin{array}{l}\text { Leading schools in the context of } \\
\text { optimally utilizing non-human school } \\
\text { resources }\end{array}$ & 0 & $\mathrm{C}$ & 5 & $\mathrm{~B}$ \\
\hline 4 & $\begin{array}{l}\text { Managing change and developing schools } \\
\text { towards effective learning organizations }\end{array}$ & 0 & SK & 0 & SK \\
\hline 5 & $\begin{array}{l}\text { Creating a school culture and climate that } \\
\text { is conducive and innovative for student } \\
\text { learning }\end{array}$ & 0 & B & 0 & B \\
\hline 6 & $\begin{array}{l}\text { Managing teachers and staff in the context } \\
\text { of empowering human resources optimally }\end{array}$ & 5 & B & 5 & B \\
\hline 7 & $\begin{array}{l}\text { Manage school facilities and infrastructure } \\
\text { in the context of optimal utilization }\end{array}$ & 0 & $\mathrm{C}$ & 5 & B \\
\hline 8 & $\begin{array}{l}\text { Managing relationships between schools } \\
\text { and the community in order to seek } \\
\text { support for ideas, learning resources and } \\
\text { funding }\end{array}$ & 0 & B & 0 & B \\
\hline 9 & Manage students in the context of & 5 & $\mathrm{~B}$ & 5 & B \\
\hline
\end{tabular}




\begin{tabular}{|c|c|c|c|c|c|}
\hline \multirow{3}{*}{ No } & \multirow{3}{*}{ Managerial Task Implementation } & \multicolumn{4}{|c|}{ Implementation } \\
\hline & & \multicolumn{2}{|c|}{ Before } & \multicolumn{2}{|r|}{ after } \\
\hline & & $\%$ & Information & $\%$ & Information \\
\hline & $\begin{array}{l}\text { acceptance of new students and placement } \\
\text { of capacity building for students }\end{array}$ & & & & \\
\hline 10 & $\begin{array}{l}\text { Manage curriculum development and } \\
\text { learning activities in accordance with the } \\
\text { direction and objectives of national } \\
\text { education }\end{array}$ & 0 & $\mathrm{C}$ & 5 & B \\
\hline 11 & $\begin{array}{l}\text { Manage school finances in accordance } \\
\text { with the principles of accountable, } \\
\text { transparent and efficient management }\end{array}$ & 0 & SK & 0 & SK \\
\hline 12 & $\begin{array}{l}\text { Manage school administration in } \\
\text { supporting the achievement of school } \\
\text { goals }\end{array}$ & 0 & SK & 0 & SK \\
\hline 13 & $\begin{array}{l}\text { Manage special service units in supporting } \\
\text { learning activities and student activities at } \\
\text { school }\end{array}$ & 70 & K & 0 & K \\
\hline 14 & $\begin{array}{l}\text { Manage school information systems in the } \\
\text { framework of program preparation and } \\
\text { decision making }\end{array}$ & 5 & K & 5 & $\mathrm{C}$ \\
\hline 15 & $\begin{array}{l}\text { Utilize information technology } \\
\text { advancements to improve learning and } \\
\text { school management }\end{array}$ & 5 & SK & 5 & SK \\
\hline 16 & $\begin{array}{l}\text { Monitoring, evaluating and reporting the } \\
\text { implementation of school activities } \\
\text { programs with appropriate procedures, and } \\
\text { planning for follow-up }\end{array}$ & 5 & K & 5 & $\mathrm{C}$ \\
\hline
\end{tabular}

Description of the Implementation of the Principal's Managerial Tasks Before the Practical Guide for School Management is Available

Based on the above table, it can be explained that the implementation of managerial tasks found in the field at the beginning of the study revealed that only $31,25 \%$ were implemented in the good category, $25 \%$ in the moderate category, $18.75 \%$ in the poor category, and $25 \%$ in the very poor category. In more detail it can be explained as follows:

1) The implementation of managerial tasks in good category (31.25\%) consists of indicators 2, 5, 6, 8, and 9 including:

a. The school principal has carried out the development of the school well, this can be seen from the formulation of the vision, mission, and goals of the school even though the school objectives formulated did not reflect the school's goals for the next 4 years.

b. The school principal has tried to create a conducive and innovative school culture and climate for the learning of students, the school has tried to create inclusive classes that give the impression that in school all students are allowed to learn without differentiating the limitations of children, schools provide more time to learn for students who need it, encouraging teachers to behave positively in the classroom so that the learning climate is good and orderly in the classroom, conveying messages to children through various ways that they can be successful and trying to make policies related to children's learning progress in school. 
c. The school principal has tried to manage teachers and staff in the framework of optimally empowering human resources, joint meetings with teachers and school administration staff have been scheduled in order to discuss learning issues, trying to motivate teachers and school administration staff to participate in development activities his professionalism both individually and collectively.

d. The school principal has tried to establish a good cooperative relationship between the school and the community in order to seek support for ideas through meetings with parents that are held at least twice a year, inviting resource persons to schools such as the police to provide traffic safety materials during the theme job learning and police sub-themes.

e. The principal has carried out the management of students well, especially in the context of acceptance of new students and placement of student capacity development. The average headmaster has made a written committee in order to accept new students, place students in accordance with the age group of children, design student capacity building programs every Saturday with various activities such as music, dance, religion, swimming, and at the end of each school year, the release of the child is done through a kindergarten graduation event and at the same time displays the results of the child's self-development during the school year.

2) Implementation of managerial tasks with sufficient categories (25\%) consists of indicators 1, 3, 7, and 10, including:

a. The principal has prepared a school work plan (RKS) for various levels of planning such as the annual work plan (RKT), but the 4-year medium term work plan (RKJM) document and school activity plan and budget document (RAKS) are not yet available.

b. The school principal sometimes includes teachers and other school staff to discuss the utilization of non-human resources in the school such as school programs, room management, equipment, educational aids, study time, and school physical appearance. Related to the utilization of school financial resources, teachers tend to be rarely invited by principals to discuss them because they are considered the authority of the foundation's management.

c. Principals in managing school facilities and infrastructure in the context of their optimal utilization have not yet made plans and procured school facilities and infrastructure in writing because they are considered to be a matter for the foundation.

d. The school principal in managing curriculum development and learning activities in accordance with the direction and objectives of national education has developed an educational unit level curriculum (KTSP) whose contents contain the vision, mission, and goals of the school but it is still limited to written in the document not yet published in school so that it can be read by the community.

3) Implementation of the principal's managerial assignments classified as less $(18.75 \%)$ consists of indicators 13.14 , and 16, among others:

a. The principal has not yet fully managed a special service unit in supporting learning activities and student activities at school. In general, schools do not have the medical personnel and medicines needed to provide first aid for children when they have an accident at school are not available, on average schools do not provide school transportation services, on average schools do not have special cleaning personnel to take care of schools, and the school does not have a school canteen service. 
b. The principal has not yet managed the school information system in the framework of program preparation and decision making in schools properly. The average school has not maximally utilized the internet and technology (IT) in delivering information to parents or to the community, schools tend to still use manual correspondence given directly to parents / guardians when delivering or picking up children to school, school too rarely have bulletin boards as a place for delivering school information to parents or the community.

c. Principals generally do not monitor and evaluate planned and written school activities, there are no written documents in the form of reports on the results of monitoring and evaluation of school activities to superiors both to the education office and to the foundation (for private schools), and to the head average schools do not follow up from the results of monitoring and evaluation of school activities carried out on a scheduled basis. The average headmaster said there was monitoring and evaluation and follow-up on all activities but it was not supported by physical evidence or complete documents.

4) The implementation of managerial tasks for school principals in the very poor category $(25 \%)$ consists of indicators $4,11,12$, and 15 , among others:

a. School principals have not optimally managed school change and development, average school quality values have not been satisfactory, they have not optimally invited school residents to determine strategies and actions to achieve the vision and mission of the school, and schools have still not been found to have tried to create pleasant learning leadership for children in school.

b. Principals generally do not manage school finances in accordance with procedures and principles of management that are accountable, transparent, efficiency and fair. In preparing the school activity plan and budget (RKAS) teachers are not included because it is considered to be the responsibility of the school principal and manager of the foundation. Spending of school funds for office and learning resources sourced from parents in the form of school fees is fully handled by the foundation. Similarly, the management of school operational assistance funds sourced from the government on average schools are handled by the foundation but in the accountability report to the government made on behalf of the school principal.

c. School principals generally have double duties in managing school administration because schools do not have school administrative staff. To deal with matters relating to the administration or administration of the school on average handled by the principal and involve the teacher after the teaching and learning process is complete.

d. The principal has not utilized information technology advancements to improve children's learning in the classroom because the school does not have an internet network that can be used to access up-to-date information or learning material, and or as a source of learning for children in the classroom. The principal also has not utilized information technology advancements in the implementation of school management so that data relating to schools is still stored only in paper documents or in flash disc, so parents or the community cannot access information about the school concerned. 


\section{The Impact of School Management Practical Guidelines on the Implementation of Principal Managerial Tasks}

Based on Table 01 above shows that with the practical guidance of school management, the implementation of managerial tasks performed by the head of the school is known to increase as bankruptcy: $56.25 \%$ of the principals' managerial tasks have been carried out in either category; $12.5 \%$ in the sufficient category; $6,25 \%$ in the less category; even though there are still $25 \%$ of principals' managerial tasks that remain in the very poor category. In more detail it can be explained as follows:

Implementation of principals' managerial tasks classified as good $(56.25 \%)$, consisting of indicators $1,2,3,5,6,7,8,9$, and 10 , include:

1) Indicator 1, the principal is able to develop the school well, this can be seen from the existence of school activity plan documents (RKS), annual work plans (RKT), trying to perfect the 4-year medium term work plan (RKJM), formulation of vision, mission and school goals that describe the goals of the school for the next four years.

2) Indicator 2, the principal can understand how to analyze the needs of the school in the context of school development by improving the formulation of the vision, mission, and medium-term goals for the next 4 years and preparing the documents.

3) Indicator 3, the principal realizes the importance of involving teachers through work meetings to discuss the utilization of school physical resources such as buildings, rooms, school equipment, teaching aids / educational media, learning time, and school physical appearance to realize school programs. The principal also realizes the importance of making minutes when leading school staff to discuss the utilization of school resources as physical evidence of accountability for activities. The school principal is committed openly to teachers and school staff discussing the utilization of existing school financial resources both sourced from the community (parents) and from the government. The school principal has done the development of the school well, this can be seen from the formulation of the vision, mission, and school goals even though the school objectives formulated do not yet describe the school goals for the next 4 years.

4) Indicator 5, the school principal has endeavored to create a conducive and innovative culture and school climate for student learning. The average headmaster together with the teacher tries to create the impression that in his school all children can learn without distinguishing the limitations of the child, the school provides more time to learn for students who need it such as having difficulty reading in the beginning, encouraging teachers to continue to behave positively in class so that good and orderly learning climate in the classroom, reminds teachers to always motivate children that they can succeed and try to make policies related to the progress of children's learning in school.

5) Indicator 6, principals increasingly understand their duties in managing teachers and staff optimally, do the division of tasks that begins with meetings with teachers and staff, make scheduled work meetings in a planned and scheduled, will try to motivate teachers and administrative staff (especially schools who have school administrative staff) for the development of sustainable professionalism both individually and collectively.

6) ) Indicator 7, the school principal understands and is aware of his duties in managing school facilities and infrastructure, is committed to making plans for school needs even though the procurement of facilities and infrastructure can be submitted to the foundation, carrying out maintenance of facilities and infrastructure according to its type, will carry out inventory of facilities and school infrastructure, and propose school 
facilities and infrastructure that are no longer appropriate to be used for removal from the school inventory list.

7) Indicator 8, principals are increasingly aware of their duties in managing relations between schools and the community in order to seek support for ideas, learning resources and school funding. School principals increasingly understand the procedures for building cooperation with other parties by making a joint agreement agreement to build schools, the school principal is committed to trying to invite speakers to the school in learning children in class in accordance with the themes or sub-themes of learning, such as the police, the medical, and else.

8) Indicator 9, school principals have a better understanding in terms of student management starting from the acceptance of new students, placement, and capacity building for students. The school principal is committed that in the framework of accepting new students will make a committee for a clear division of tasks. Placement of new students is in accordance with the grouping of classes based on the age of the child.

9) Indicator 10, principals have a better understanding of management in curriculum development and learning activities in accordance with the direction and objectives of national education. The average school principal is committed to reviewing the vision, mission, and goals of the school and publicizing it in the school environment, and reviewing the KTSP to include local content of the school, create programs and submit to the organizers (foundations) to improve the ability of teachers on techniques to guide children according to the right procedure by assigning teachers through workshops or inviting guidance and counseling (BK) experts from educational institutions and education staff (LPTK).

The implementation of managerial tasks for school principals is classified as sufficient (12.5\%), including indicators 14 and 16

1) Indicator 14, principals are starting to realize the importance of managing school information systems in the context of preparing programs and making decisions in schools properly. The average school principal is committed to trying to use the internet and technology (IT) in the delivery of information to parents and to the community such as through WhatsApp the principal / teacher even though still using manual correspondence given directly to parents / guardians when delivering and picking children up to school. In addition to this to convey general school information, the school principal is committed to making the best use of the bulletin boards available at the school.

2) Indicator 16, the principal has realized the importance of monitoring and evaluating the planned and written implementation of school activities. There is a commitment of school principals to conduct planned and scheduled monitoring and evaluation of school activities, to make written reports as evidence of the monitoring and evaluation of principals' activities to superiors both to the education office and to the foundation (for private schools), and to the principal the average committed will follow up on the results of monitoring and evaluation of school activities carried out on a scheduled basis. The average school principal supports the need to monitor and evaluate and follow up on all school activities in order to realize the quality of learning in schools. 
The implementation of managerial tasks of school principals that are classified as less $(6.25 \%)$ includes indicator 13 , namely:

Indicator 13, the principal has not yet managed a special service unit in supporting learning activities and student activities in the school. In general, schools do not have medical personnel and medicines needed to provide first aid (P3K) for children if there is an accident at school is not available, on average schools do not provide school transportation services, do not have special hygiene personnel to take care of schools so that hygiene the school is still the responsibility of the teacher, and the school does not have a school canteen service that can be managed as a form of school entrepreneurship competence.

The implementation of managerial tasks for school principals is classified as very poor (25\%) including indicators $4,11,12$, and 15 .

1) Indicator 4, Managing changes and developing schools towards an effective learning organization, meaning that the principal has not maximally led the school community to determine and fight for the school quality values because the average school quality scores have not been satisfactory, not yet maximally inviting school residents to determine strategies and action to achieve the vision and mission of the school, even though the principal has tried to create enjoyable learning leadership in the school.

2) Indicator 11, principals generally do not manage school finances in accordance with procedures and principles of management that are accountable, transparent, efficiency and fair. In preparing the school activity plan and budget (RKAS) teachers are not included because it is considered to be the responsibility of the school principal and manager of the foundation. Spending school funds for office needs and learning sourced from parents in the form of school fees is fully handled by the foundation. Similarly, the management of school operational assistance funds sourced from the government on average schools are handled by the foundation but in the accountability report to the government made on behalf of the school principal.

3) Indicator 12, principals generally hold the task of managing school administration because schools do not have school administrative staff. To deal with matters relating to the administration or administration of the school on average handled by the principal directly and involve the teacher after the teaching and learning process is finished so that it seems the teacher's task concurrently additional tasks for school administration management.

4) Indicator 15, school principals have not utilized information technology advancements to improve children's learning in the classroom because schools do not have an internet network that can be used to access up-to-date information or learning material, and or as a source of learning for children in the classroom. The principal also has not utilized information technology advancements in the implementation of school management so that data relating to schools is still stored only in paper documents or in flasdisc, so parents or the community cannot access information about the school concerned.

Based on the results of the research above, it can be concluded that there is a positive impact of the practical guidelines of school management on the implementation of managerial duties of school principals, although there are still indicators that persist in the very poor category, which is basically not because the ability of principals to carry out managerial tasks is poorly understood. but because of the policy of the school organizer that must be followed by the school principal. 


\section{Conclusion}

Based on the results of the study it was concluded that the impact of the availability of practical guidelines for school management showed that there was a change in the implementation of school managerial task management towards a better direction. Indicators that have been implemented become good categories (56.25\%), namely: compiling school plans for various levels of planning; develop schools according to need; lead the school in the context of optimally utilizing non-human school resources; creating a school culture and climate that is conducive and innovative for student learning; managing teachers and staff in the context of optimizing human resources; manage school facilities and infrastructure in the context of efficient utilization; managing relationships between schools and the community in order to seek support for ideas, learning resources and financing; manage students in the context of acceptance of new students and placement of capacity building for students; and manage curriculum development and learning activities in accordance with the direction and objectives of national education. Indicators belonging to the sufficient category (12.5\%), namely: managing school information systems in the framework of program preparation and decision making; and monitoring, evaluating and reporting the implementation of school activities programs with appropriate procedures, and planning for their follow-up.

Indicators belonging to the less category $(6,25 \%)$, namely: managing special service units in supporting learning activities and student activities in schools; however, there are still indicators of managerial tasks that are classified as very poor $(25 \%)$ due to the policies of the school administrators which must be followed by the principal: managing change and developing schools towards effective learning organizations; school financial management in accordance with the principles of accountable, transparent and efficient; management of school administration in supporting the achievement of school goals; and utilize information technology advancements to improve learning and school management.

Based on the above conditions, it is suggested that there is a need to foster and develop the principal's managerial abilities through training activities and school principals' workshops with the aim of adding insight into the principal's knowledge and skills in carrying out the principal's managerial management tasks in order to realize quality learning in schools. In addition to this, school administrators should fully support the management of schools handed over to the school principal so that the school institution is truly professionally managed.

\section{References}

[1] Undang-Undang Sistem Pendidikan Nasional, No. 20 Tahun 2003.

[2] Peraturan Mentri Pendidikan dan Kebudayaan No. 137 Tahun 2014.

[3] Sagala, Syaiful. (2005), School \& Community Based Management; Strategy to Win Quality Competition. Jakarta: Nimas Multima.

[4] Lecturer Team. (2009), Educational Management. Bandung: Alfabeta.

[5] Terry, G.R. (1978) Principles of Management. 7th Ed. Homewood Illinois. Richard D. Irwin Inc.

[6] Kartono, Kartini. (1994), Social Psychology for Corporate and Industrial Management. Jakarta: Raja Grafindo Persada.

[7] Stoner, James A.F. \& Wankel, Charles. (1986), Management. 3th Ed. New York: Prentice Hall. 
[8] Daft, Richard L. (2006), Management. 6th-Ed. Singapore: Thomson Learning.

[9] Albers, H. (1972), Management. The Basic Concept. New York: John Wiley \& Son.

[10] Drucker, Feter F. (1976), The Effective Executive. New York: Harper \& Row.

[11] Hersey, Paul \& Blanchard, Kenneth H. (1982), Management of Organizational Behavior (Unilizing Human Resources). 3th Ed. New Delhi: Prentice Hall.

[12] Robbins, Stephen P. \& Coulter, Marry. (2007), Management. 8ed. Subtitles in Harry Slamet. Jakarta Index.

[13] Danim, Sudarman and Khairil, (2010), Educational Profession. Bandung: Alfabeta.

[14] Nova Setiawan, (2019), Effect of Principal's Managerial Ability on School Effectiveness in SMA Negeri 2 Bandar Lampung. (https:/www.e-jurnal.com/2015/11/p affect- ability managerial- head.html, accessed May 15.

[15] Bandi and Supriyoko. (2019), Contributions of Principal's Managerial Ability, Teacher Teaching Experience, and Utilization of Learning Facilities on Teacher Performance. Journal of Educational Management Media, 2 (1).

[16] Adi Anwar Faisal. (2019), The Influence of Managerial Ability on the Performance of Teachers of Public Elementary Schools in Yogyakarta's Kotagede District. (https://www.e-jurnal.com/2017/03//flu-certility-managemential-head.html).

[17] Engkay Karweti. (2019), Effect of Principal's Managerial Ability and Work Motivation on the Performance of SLB Teachers in Subang Regency.

[18] Sugiyono. (2014), Educational Research Methods. Quantitative, Qualitative, and R\&D Approaches. Bandung: Alfabeta. 